\title{
Risk management to ensure the exploitation reliability of high-rise buildings
}

\author{
Marina Dement'eva ${ }^{*}$, Ilya Terekhin and Anastasiya Lebedeva \\ Moscow State University of Civil Engineering, Yaroslavskoe shosse, 26, Moscow, 129337, Russia
}

\begin{abstract}
The paper presents the results of a study of design risks affecting the exploitation reliability of high-rise buildings. The aim of the study was to study and optimize risk management strategies. The relevance of the work is justified by the statistics of recorded violations in the design of high-rise buildings, which affects their quality in the process of exploitation, leading to disastrous consequences. Existing methods of risk assessment take into account natural and man-made hazards. The consequences of risk are human victims. Damage to risk is estimated from material losses. The paper suggests refinement to the methodology for assessing project risks. As a criterion of the consequences of risks, the deviation from the normative technical condition is proposed. As a criterion of damage, the value of operating costs, as well as the amount of costs for eliminating not the consequences of risks, but the costs of eliminating their causes at the design stage are proposed. The risk classification was carried out according to the design stages, according to the source of occurrence. The ranking of risk criteria was proposed to establish the priority of their elimination. The algorithm of risk management proposed by the authors can serve as an addition to existing quality control systems for the stage of designing high-rise buildings.
\end{abstract}

\section{Introduction}

High-rise buildings are an integral part of the modern city. They are also part of the housing and communal services, since they provide the need for housing, are included in the social, household, retail and entertainment services of the urban population. In addition, high-rise buildings are connected to the general system of public utilities and are large consumers of resources. As the data on the construction of high-rise buildings [1] show, there is a tendency to increase their height by approximately 1 floor per year. The average height of the world's 100 tallest buildings has more than doubled in 80 years.

High-rise buildings belong to unique objects. They are performed on atypical project solutions. This complicates the process of research, design, preparation for construction and increases project risks. Obviously, at the stage of exploitation of high-rise buildings, the underestimated design risks can lead to serious, even catastrophic consequences. For example, the analysis of the consequences of fires in skyscrapers, showed that the

\footnotetext{
* Corresponding author: 7dem@mail.ru
} 
development factors of the tragic events are violations in the design and exploitation [2]. In particular, this is a discrepancy between the design, structural, space-planning characteristics of buildings for safety requirements, the unavailability of exploitation services for actions in emergency situations. Therefore, the most important problem is to assess the impact of project risks on the safety of high-rise buildings during exploitation.

Analysis of the regulatory and legal framework in the construction and exploitation of high-rise buildings shows that the main directions for ensuring their reliability are technical measures, namely the development of a monitoring system for the technical parameters of structures and building systems, quality control of materials used in the construction process, risk assessment in emergency situations of natural or of anthropogenic origin [3, 4]. In particular, when calculating project risks, those that result in injuries or loss of life, as well as significant material damage from their consequences, are taken into account. At the same time, the methods do not address the issues of assessing the impact of design risks on the deviation of technical and economic characteristics of buildings from design values even at the stage of their commissioning. Such deviations can lead not only to emergency situations, they affect the rate of deterioration of buildings, lead to a decrease in their durability, increase the cost of their subsequent operation, i.e. do not allow to ensure the required quality of exploitation.

A survey of studies in the risk assessment of high-rise buildings shows [5-13] that they are devoted to the development of methods for minimizing risks, taking into account the technical features of designing and building high-rise buildings, as well as the investment attractiveness of such projects. At the same time, the problem of ensuring the exploitation reliability of high-rise buildings remains relevant.

The hypothesis of the study is the need to add to the methodology for assessing project risks. It is necessary to take into account their influence not only on the safety of use in terms of the likelihood of loss of life, but also on the loss of suitability for the exploitation of individual structures and building systems.

To solve the problem studied in the work, it is suggested to consider the influence of design risks on the value of exploitation reliability. This indicator can be considered as a multivariate value characterizing the design risks that are manifested during the exploitation phase and affecting the retention in time of both technical and economic design indicators.

Therefore, the purpose of the study is to develop an algorithm for making managerial decisions to reduce the consequences of the risks of violations occurring during the design of high-rise buildings to ensure their exploitation reliability.

To achieve this goal, it is necessary to solve the following tasks:

1. To study the components of risk at the stage of designing a high-rise building.

2. Propose criteria for assessing the design risks of high-rise buildings.

3. Carry out a qualitative analysis of the consequences of project risks.

4. To establish the danger of the impact of design risks on the exploitation reliability of high-rise buildings.

5. To propose a risk management algorithm for making decisions to ensure exploitation reliability in the design of high-rise buildings.

\section{Materials and Methods}

The object of research was the risks arising during the design phase and affecting the exploitation reliability of high-rise buildings. The subject of the study was the study of the principles of project risk management to reduce their impact on the exploitation reliability of high-rise buildings. The following assumptions were made:

1. The design phase is the time interval from the beginning of the concept of a high-rise building to its commissioning. 
2. Risks have one consequence - a decrease in operational reliability.

3. Damage is associated with the deterioration of the technical condition of structures and building systems, as well as the economic inefficiency of their exploitation.

These assumptions formed the basis for the research methodology and the definition of criteria for assessing project risks. A conceptual risk analysis implies [14-16]:

- determination of criteria for assessing project risks;

- System analysis of dangerous events and their consequences arising during the design of high-rise buildings;

- expert assessment of the severity and damage of risks;

- Analysis of the need to optimize the design phase by developing proposals for risk management with the worst consequences and damage.

In accordance with [3], the criteria for risk assessment is the mathematical expectation of its consequences, taking into account the probability of its manifestation:

$$
E\left(R_{i}\right)=f\left(C_{i} \cdot p_{i}\right)
$$

where $\mathrm{E}\left(\mathrm{R}_{\mathrm{i}}\right)$ is the mathematical expectation of the consequences of the risk arising from the realization of the $\mathrm{i}$-th dangerous event; $\mathrm{C}_{\mathrm{i}}$ - the severity of the consequences when implementing the $\mathrm{i}$ th event; $p_{i}$ is the probability of realizing the $i$-th dangerous event.

In work as a criterion for assessing the severity of the consequences of risk is the degree of non-compliance of safety indicators, namely, the category of technical condition $\mathrm{k}$, characterizing the probability of deviation from the operable state and the onset of the limiting state. As a criterion for assessing the damage, the impact of risk is the degree of inconsistency of the economic indicators, namely, the amount of deviation of exploitation costs from the planned design value of $\mathrm{S}_{\mathrm{i}}$. When planning impacts on project risks, the costs for this minimizing $S_{R i}$ should also be considered.

Analyzing the regulatory requirements for the values of the exploitation characteristics and their correspondence to the categories of technical condition, energy costs, etc., a classification of risk levels was developed according to the criteria of severity and damage based on the method of peer review: maximum permissible, acceptable, reasonable, negligible (Table 1).

Table 1. Ranking of project risks by severity and damage based on the method of peer review.

\begin{tabular}{|c|c|c|c|c|}
\hline \multirow{2}{*}{ Criterion of risk } & \multicolumn{4}{|c|}{ Project Risk Scale } \\
\cline { 2 - 5 } & IV & III & II & I \\
\hline Interpretation & Negligible risk & $\begin{array}{c}\text { Acceptable } \\
\text { risk }\end{array}$ & $\begin{array}{c}\text { Reasonable } \\
\text { risk }\end{array}$ & $\begin{array}{c}\text { Maximum } \\
\text { permissible risk }\end{array}$ \\
\hline $\begin{array}{c}\text { Name of the category of } \\
\text { technical condition } \\
\Delta \mathrm{k}_{\mathrm{i}}\end{array}$ & Serviceable & Workable & $\begin{array}{c}\text { Limited } \\
\text { working } \\
0.31-0.6\end{array}$ & Limit \\
\hline $\begin{array}{c}\text { Exploitation costs } \\
\Delta \mathrm{S}_{\mathrm{i}}\end{array}$ & $\begin{array}{c}\text { Correspond to the } \\
\text { project }\end{array}$ & $\begin{array}{c}\text { Slight } \\
\text { deviation } \\
<0.1\end{array}$ & $\begin{array}{c}\text { Small } \\
\text { deviation } \\
0.1-0.3\end{array}$ & $\begin{array}{c}\text { Significant } \\
\text { deviation } \\
>0.3\end{array}$ \\
\hline $\begin{array}{c}\text { Costs for eliminating } \\
\text { (minimizing) the risk }\end{array}$ & Slight & Small & Significant & Essential \\
$\mathrm{S}_{\mathrm{Ri}}$ & $<0.1$ & $0.1-0.2$ & $0.21-0.5$ & $>0.5$ \\
\hline
\end{tabular}

The total index of the IR of the project risk on operational reliability can be established using matrices of 1 and 2 order (Fig. 1). In the first order matrix, the effect of the project risk on the category of technical condition $\mathrm{k}_{\mathrm{i}}$ and the exploitation costs of $\mathrm{S}_{\mathrm{i}}$ is determined. 
The second order matrix takes into account the exploitation reliability $\mathrm{R}_{\mathrm{i}}$ and the risk minimization costs $\mathrm{S}_{\mathrm{Ri}}$ :

$$
I_{R}=f\left(k_{i} ; S_{i} ; S_{R i}\right)
$$

In this case, the following assessment of the priority of elimination of risk is established: low - 4; average - 3; high - 2; first priority - 1 .
$\mathrm{k}_{\mathrm{i}}$
II III IV
$\mathrm{R}_{\mathrm{i}}$ I II III IV

$\mathrm{S}_{\mathrm{i}}$

I

II

III

IV

\begin{tabular}{|l|l|l|l|}
\hline 1 & 1 & 3 & 4 \\
\hline 1 & 2 & 3 & 4 \\
\hline 1 & 2 & 4 & 4 \\
\hline 1 & 3 & 4 & 4 \\
\hline
\end{tabular}

$\mathrm{S}_{\mathrm{Ri}}$

I

II

III

IV

\begin{tabular}{|l|l|l|l|}
\hline 1 & 1 & 2 & 3 \\
\hline 1 & 2 & 3 & 4 \\
\hline 1 & 2 & 3 & 4 \\
\hline 1 & 2 & 3 & 4 \\
\hline
\end{tabular}

Fig.1. Matrices 1 and 2 order to establish the priority of eliminating project risks.

\section{Results}

The second point of the research program was the study of dangerous events and their consequences arising during the design of high-rise buildings. Using the analogy method, probable design risks affecting the exploitation reliability were analyzed (Table 2).

Also during the research, the risks at the stage of designing a high-rise building were classified into groups by source of origin (Figure 2).

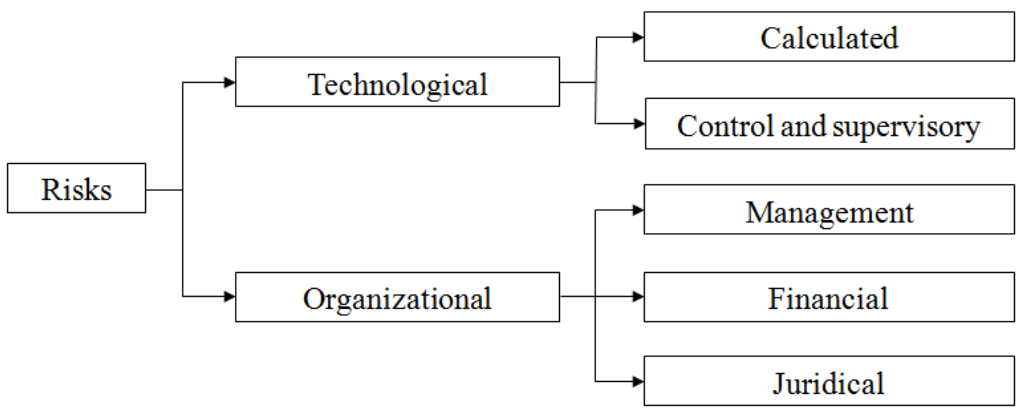

Fig. 2. Classification of design risks by source of occurrence.

The calculated risks include:

- development of project documentation;

- calculations of load-bearing structures, foundations and foundations;

- calculations for the progressive collapse of buildings;

- expert opinion on the projects of load-bearing, enclosing, separate structures, foundations and foundations;

- fire risk assessment;

- scientific and technical support for the design of the facility.

The control and supervisory risks include:

- scientific and technical expert opinion on the possibility of using a piling foundation;

- architectural supervision of construction;

- support of model aerodynamic tests and development of recommendations for the designation of calculated snow and wind loads;

- testing of a large-scale model;

- examination of project documentation; 
Table 2. The main stages of the construction project, their content and risks.

\begin{tabular}{|c|c|}
\hline Stage of occurrence of risk & Project risk \\
\hline \multicolumn{2}{|c|}{ Development of a feasibility study } \\
\hline $\begin{array}{l}\text { - Definition of the project framework } \\
\text { - Development of a project strategy } \\
\text { - Creation of a project team } \\
\text { - Division of responsibility } \\
\text { - Preparation of technical } \\
\text { specifications } \\
\text { - Approval of project deadlines and } \\
\text { budget } \\
\text { - Approval of document circulation } \\
\text { procedures }\end{array}$ & $\begin{array}{l}\text { - Risk of inaccurate calculation of project payback } \\
\text { - The risk of underestimation of the construction budget } \\
\text { - Risk of underestimation of construction time } \\
\text { - Errors in developing an organizational chart for project } \\
\text { management } \\
\text { - The risk of making an error when selecting the main } \\
\text { technological scheme and the main technological parameters } \\
\text { of the facility }\end{array}$ \\
\hline \multicolumn{2}{|r|}{ Design } \\
\hline $\begin{array}{l}\text { - Selection of the general designer } \\
\text { - Project management } \\
\text { - State expertise of the project } \\
\text { - Preparation of a tender for } \\
\text { construction } \\
\text { - Management of working design } \\
\text { - Financial control }\end{array}$ & $\begin{array}{l}\text { - Errors in the development of project documentation } \\
\text { - Errors in the development of specifications } \\
\text { - Risk of failure of state expertise } \\
\text { - Errors in the development of budget documentation } \\
\text { - Risk of non-receipt of the set of executing documentation } \\
\text { - Project documentation is developed simultaneously with the } \\
\text { construction } \\
\text { - Risk of affiliation of the general designer and the general } \\
\text { contractor } \\
\text { - Risk of taking preconceived design decisions } \\
\text { - Risk of using materials that have no analogues }\end{array}$ \\
\hline \multicolumn{2}{|r|}{ Building } \\
\hline $\begin{array}{l}\text { - Selection of the general contractor } \\
\text { - Approval of the project at the stage } \\
\text { of the working documentation } \\
\text { - Launching the project in production } \\
\text { - Organization of architectural } \\
\text { supervision } \\
\text { - Construction management } \\
\text { - Technical supervision, acceptance } \\
\text { of works and quality control } \\
\text { - Financial control }\end{array}$ & $\begin{array}{l}\text { - Opacity in selecting contractors and suppliers } \\
\text { - Non-fulfillment of obligations by contractors and equipment } \\
\text { suppliers } \\
\text { - Failure to comply with process regulations for construction } \\
\text { and installation works } \\
\text { - Late receipt of information on changes in design decisions, } \\
\text { cost, timing of delivery of interim works } \\
\text { - Overestimate the cost of materials, works, equipment } \\
\text { - Use of materials that do not correspond to project solutions } \\
\text { - Manipulating the costs and margins of the project } \\
\text { - Risks of increasing the construction time }\end{array}$ \\
\hline \multicolumn{2}{|r|}{ Commissioning works } \\
\hline $\begin{array}{l}\text { - Testing and testing of all systems } \\
\text { - Completion of contracts with } \\
\text { contractors } \\
\text { - Transfer of the object into } \\
\text { exploitation } \\
\text { - Final report, conclusions on the } \\
\text { results of the project implementation }\end{array}$ & $\begin{array}{l}\text { - Risk of failure to achieve project technical indicators } \\
\text { - Risk of untimely commissioning of the facility }\end{array}$ \\
\hline \multicolumn{2}{|c|}{ Putting the object into exploitation } \\
\hline $\begin{array}{l}\text { - Completion of contracts with } \\
\text { contractors } \\
\text { - Transfer of the object into } \\
\text { exploitation } \\
\text { - Final report, conclusions on the } \\
\text { results of the project implementation }\end{array}$ & $\begin{array}{l}\text { - Failure to obtain a package of licensing documents } \\
\text { - High corruption component in the legalization of high-rise } \\
\text { buildings }\end{array}$ \\
\hline
\end{tabular}


- tests to determine the coefficient of base compaction and backfilling of engineering networks;

- development of recommendations on the designation of components in the selection of concrete composition;

- evaluation of the bearing capacity of friction joints on high-strength bolts;

- evaluation of the load-bearing capacity of the cover joints;

- development of technical specifications for the manufacture of steel structures;

- development of technical specifications for the installation of metal structures.

Financial risk is associated with the possibility of the company failing to meet its financial obligations. The main reasons for financial risk are:

- depreciation of the investment and financial portfolio due to changes in exchange rates;

- failure to make payments.

The reasons for juridical risks are:

- underestimation of the requirements of legislation or their change during the transaction period;

- discrepancy of legislations of the different countries;

- incorrectly prepared documentation, as a result of which the counterparty is unable to fulfill the terms of the contract.

Managerial risk is associated with a possible chance of making a profit and the likelihood of loss due to illiterate techniques of management of the organization.

Based on the analysis carried out and the risk classification performed, a diagram of the causes and consequences of Ishikawa was plotted to illustrate the systematized possible reasons for the failure to ensure exploitation reliability (Fig. 3). Taking into account the above assumptions, two consequences were analyzed: 1 - limiting technical condition, 2 increase of exploitation costs.

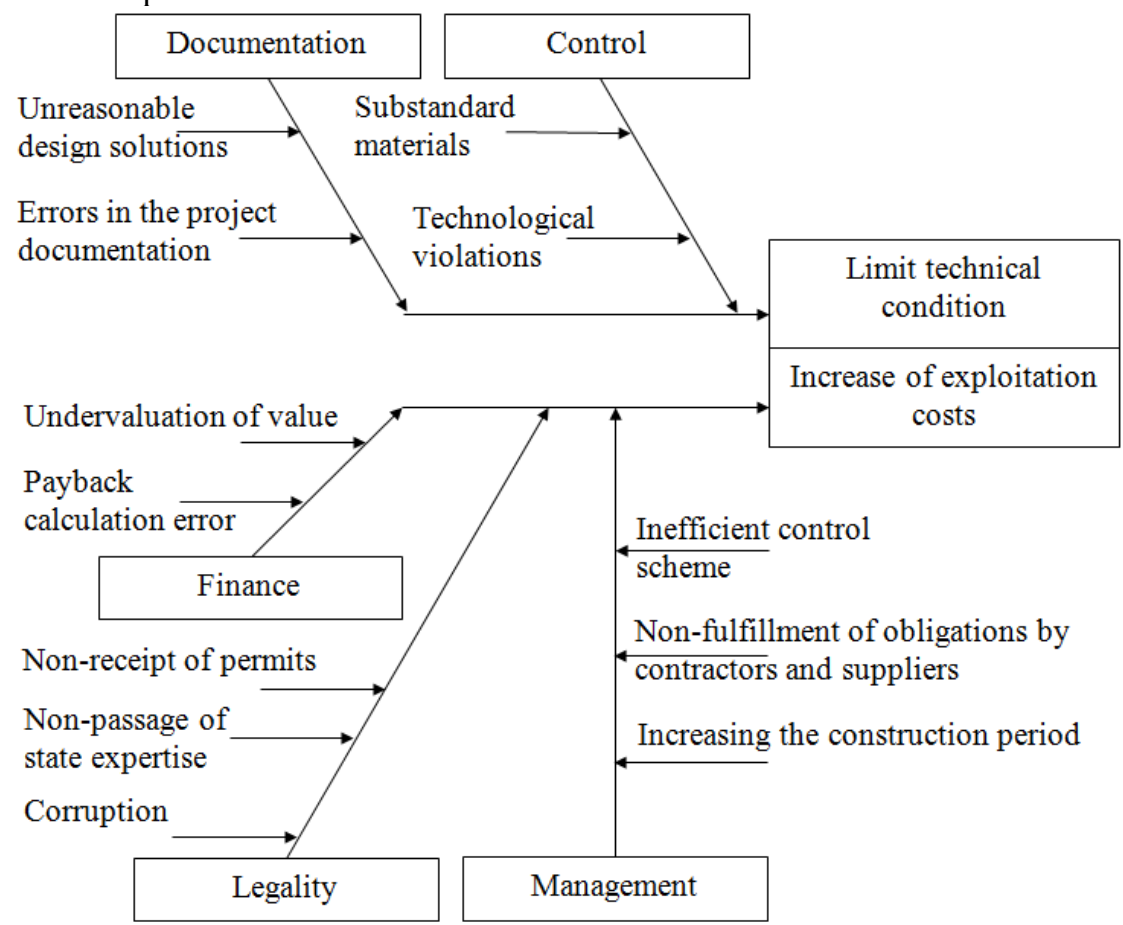

Fig. 3. Diagram of causes and consequences of systematized risks of deterioration of exploitation reliability. 


\section{Discussion}

The significance of the results obtained is that the refinement of the methodology for calculating risks allows one to take into account the consequences of design violations and their effect on reducing the exploitation reliability of high-rise buildings. Based on the developed scale of the project risks ranking, it is possible to determine the priority directions for eliminating risk situations, thereby improving the quality of the stage of designing high-rise buildings as objects of increased responsibility. An example of using the technique is shown in Table. 3.

Table 3. An example of an expert evaluation of priority criteria for eliminating project risks.

\begin{tabular}{|c|c|c|c|c|}
\hline Project risk & $\begin{array}{c}\text { Consequence } \\
\text { (effect on } \\
\text { technical } \\
\text { condition) }\end{array}$ & $\begin{array}{c}\text { Damage } \\
\text { (impact on } \\
\text { exploitation } \\
\text { costs) }\end{array}$ & $\begin{array}{c}\text { Damage } \\
\text { (cost of } \\
\text { elimination) }\end{array}$ & $\begin{array}{c}\text { The result of the } \\
\text { priority } \\
\text { evaluation }\end{array}$ \\
\hline $\begin{array}{c}\text { Technological } \\
\text { violations }\end{array}$ & II & II & I & 1 \\
\hline $\begin{array}{c}\text { Underestimation of } \\
\text { project cost }\end{array}$ & III & I & III & 3 \\
\hline $\begin{array}{c}\text { Error calculating } \\
\text { constructions }\end{array}$ & I & III & I & 1 \\
\hline $\begin{array}{c}\text { Use of poor- } \\
\text { quality materials }\end{array}$ & II & III & II & 2 \\
\hline
\end{tabular}

Also, based on the studies, a risk management algorithm was developed (Figure 4). Three strategies are adopted as risk management strategies in accordance with [15]:

1. The transfer of risk by distribution with the main counterparties includes warranty obligations.

2. Transfer of risk to professional agents involves insurance.

3. Risk retention, which includes views of different types of reservations.

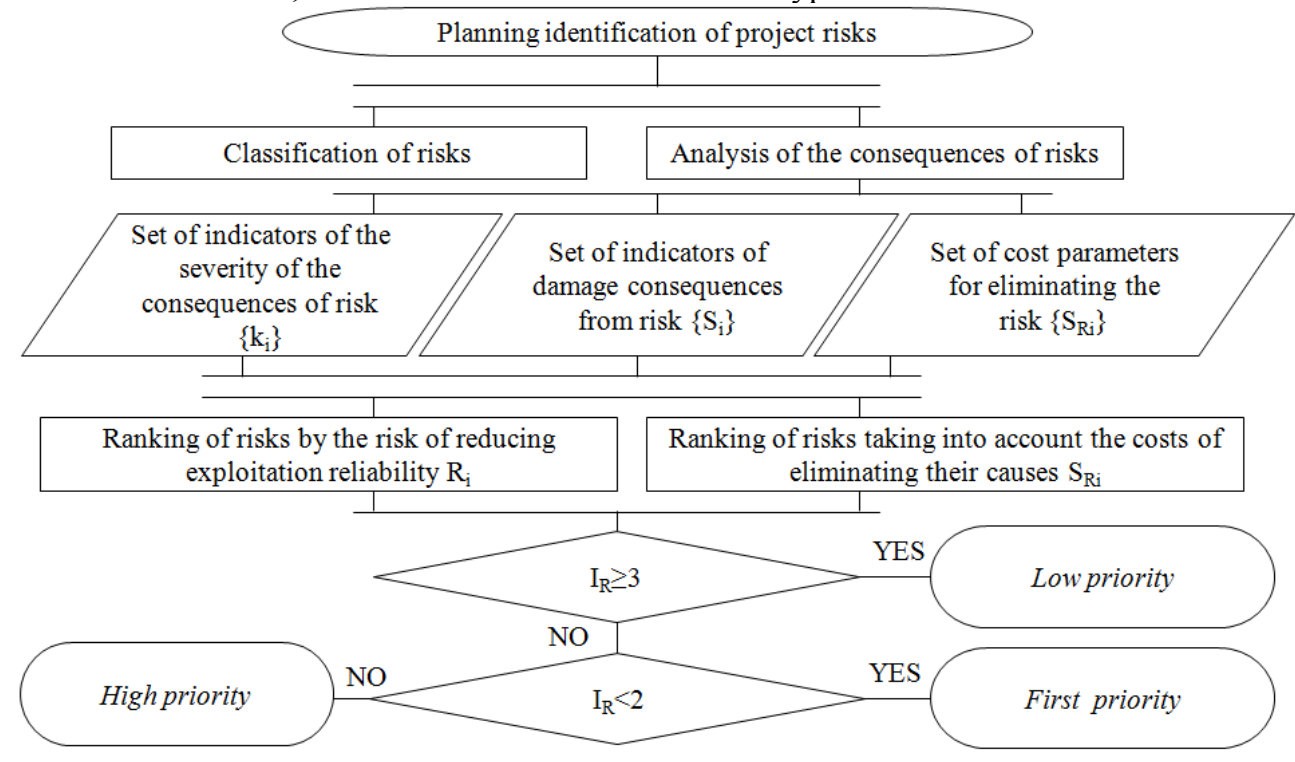

Fig. 4. Algorithm for managing project risks. 


\section{Conclusions}

The goal set in the work was achieved by solving the following tasks:

1. The risks of the main stages of the construction project were studied, their content was analyzed.

2. The classification of design risks by source of occurrence was carried out.

3. A diagram was developed of the causes and consequences of the risks of deterioration in the exploitation reliability of high-rise buildings.

4. A criterion for assessing the severity of the consequences of risk was suggested-the category of technical condition as an indicator of the onset of the limiting state, as well as criteria for assessing damage - deviation of exploitation costs from the design value and costs for minimizing risks.

5. A ranking of project risks was performed and an example of priority evaluation for their elimination was given.

6 . The risk management strategies were analyzed and a risk management algorithm was proposed.

The practical significance of the proposed risk management mechanism lies in the fact that it serves as another step in the quality control system of the project, both in terms of ensuring the quality of the facility itself during exploitation and the quality of the subsequent exploitation from the perspective of resource costs.

The novelty of the study lies in the developed system of risk ranking on a complex indicator of exploitation reliability.

\section{References}

1. URL:http://www.ctbuh.org/LinkClick.aspx?fileticket=M7nXrLx8g0M\%3d\&tabid=110 8\&language $=\mathrm{en}-\mathrm{GB}$

2. URL: http://garantpb.ru/articles/9/

3. Russian Standard STO NOSTROY 2.35.73-2012 (2012)

4. Russian Standard GOST R ISO 13824-2013 (2013)

5. S.N. Bogachev, A.A. Shkolnikov, R.A. Rozentul, N.A. Klimova, Academia. Architecture and Construction, 1, 88-92 (2015)

6. K. Jayasudha, B. Vidivelli, ARPN Journal of Engineering and Applied Sciences, 11, 6943-6950 (2016)

7. Russian Standard GOST 27751-2014 (2014)

8. A.U. Tumanov, N.V. Peganov, V.A. Tumanov, Problems of safety and emergency situations, 3, 35-40 (2018)

9. S.P. Korol, Modern management technologies, 2, 28-37 (2016)

10. M. Dement'eva, MATEC Web of Conferences, 117, 00037 (2017)

11. S. AbouRizk, Journal of Construction Engineering and Management, ASCE, 136, 1140-1153 (2014)

12. V.A. Akristiniy, Y.I. Boriskina, E3S Web of Conferences, 33, 01041 (2017)

13. M. Dement'eva, IOP Conf. Series: Earth and Environmental Science, 90, 012052 (2017)

14. Russian Standard RD 03-418-01 (2001)

15. Russian Standard GOST R 51901.5-2005 (2005)

16. Russian Standard GOST R ISO 13824-2013 (2013) 